DOI: https://doi.org/10.47405/mjssh.v6i10.1080

\begin{tabular}{|c|c|}
\hline 4 & Malaysian Journal of Social Sciences and Humanities (MJSSH) \\
\hline $\begin{array}{l}\text { Malaysian Juoural of } \\
\text { Social ccciecces and }\end{array}$ & Volume 6, Issue 10, October 2021 \\
\hline (MJ-sSH) & e-ISSN : 2504-8562 \\
\hline & $\begin{array}{l}\text { Journal home page: } \\
\text { www.msocialsciences.com }\end{array}$ \\
\hline
\end{tabular}

\title{
Re-Examining the Publicity, Advertising and Marketing of Legal Profession in Malaysia
}

\author{
Mohd Bahrin Bin Othman', Faridah Binti Hussain'1, Hariz Sufi Bin Zahari', \\ Sarah Munirah Binti Abdullah', Kemala Binti Alang ${ }^{2}$ \\ 1Faculty of Law, Universiti Teknologi MARA, 40450 Shah Alam, Selangor, Malaysia \\ ${ }^{2}$ Messrs. Balasingam \& Co., Advocates and Solicitors, No. 31, $1^{\text {st }}$ Floor, Jalan Melayu, 50100 Kuala Lumpur, Malaysia
}

Correspondence: Mohd Bahrin Bin Othman (mohdb916@uitm.edu.my)

\begin{abstract}
The legal practitioners in Malaysia are restricted from publicising, advertising and marketing themselves on the grounds of fiduciary relationship with clients, the duty to serve the public and it is professionally undignified. Despite the advancement of the Information, Communication and Technology, lawyers are restricted in utilising it for publicity, advertising and marketing. At the same time, the public is deprived of information to engage the best lawyers of their choice. Furthermore, while other countries such as European Union, United Kingdom, Singapore and Australia have moved forward, the Malaysian legal profession remains unchanged. This concept paper investigates the adequacy of the Legal Profession (Publicity) Rules 2001(“LPPR 2001") in legalising publicity, advertising and marketing. This paper adopts a qualitative research methodology with doctrinal and comparative approaches. Firstly, this paper focuses on content analysis of statutes as the primary source of law. Secondly, content analysis on secondary sources of law including journal articles, and online sources. Thirdly, conducting a comparative study by analysing the primary and secondary sources of law in other jurisdictions. This paper explains that lawyers must be allowed to innovate into new methods in publicising, advertising and marketing themselves. Society will greatly benefit from this as they will be more informed and knowledgeable in engaging the service of lawyers of their choice. This paper ends by suggesting that there is a dire need to legalise the publicity, advertising and marketing of the legal profession in Malaysia. Thus, this research is significant to the development of the legal profession in Malaysia.
\end{abstract}

Keywords: legal profession, legal publicity, legal marketing

\section{Introduction}

Most legal practitioners are attempting to publicise, advertise and market their services in a new, different and creative way especially in the time of the COVID-19 pandemic. However, the lawyers and legal firms are bound to adhere strictly to its governing laws and regulation namely, the Legal Profession Act 1976 ("LPA 1976"), the Legal Profession (Practice and Etiquette) Rules 1978 ("LPPER 1978") and Legal Profession (Publicity) Rules 2001 ("LPPR 2001"). The LPPR 2001, in particular, restrics the publicity, advertising and marketing activities to approved information. Thus, denying the legal practitioners from fully utilising the advancement of the Information, Communication and Technology (ICT). Subsequently, the public also has restricted opportunity to make a more informed choice when engaging the lawyers of their choice. While other jurisdictions such as the European 
Union ("EU"), United Kingdom ("UK"), Singapore and Australia have reformed their laws and regulation, the LPPR 2001 remains intact. Given the lack of such academic research and writing on this particular issue, this paper investigates the adequacy of the LPPR 2001 in legalising the publicity, advertising and marketing of the Legal Profession in Malaysia.

The paper proceeds as follows. Firstly, it provides a discussion on the concept of publicity, advertising and marketing in general. Secondly, it narrowed the discussion on the publicity, advertising and marketing specifically of legal practice. Thirdly, it explains the methodology of the study that resulted from this paper. Fourthly, this paper provides the background of the legal profession in Malaysia and discuss the provisions of the law concerning the publicity, advertising and marketing of the legal profession. Fifthly, the paper will discuss the need to re-examine the current provision of LPPR 2001. In doing so, this paper will also provide a comparative discussion with the position in the EU, UK, Australia, Singapore and United States ("US"). This paper concludes by suggesting that there is an urgent need to reform the LPPR 2001, hence, legalising the publicity, advertising and marketing of the legal profession in Malaysia

\section{The Concept of Publicity, Advertising and Marketing}

Publicity, advertising and marketing are interrelated to each other. Thus, it is necessary to look into the respective concept. Publicity is defined as the activity of making certain that someone or something attracts a lot of interest or attention from many people or the attention received as a result of this activity (Cambridge Dictionary, 2021). It refers to the placement, free of charge, generally in the media, of informative messages about a company or a product (Simon, 2020). Essentially, it is the media attention for a product, service, or business (Lake, 2020). It involves a planned and structured manner to promote a company or a brand to the potential customer through media coverage and other forms of communication (mba skool, 2021).

Advertising is defined as the business of trying to persuade people to buy products or services (Cambridge Dictionary, 2021). It is any paid form of non-personal presentation and promotion of ideas, goods and services through mass media such as newspapers, magazines, television or radio by an identified sponsor (Kotler, 1984). This definition mainly explains what advertising is and helps in distinguishing advertising from other communication initiatives with which it is often confused. Therefore, advertising is not the same as publicity (Devika, 2021). The role of advertising is to create demand for a product. In such a way, marketing is often perceived as a way to sell something that people do not want or need (Puspitasari \& Mohamad Permana, 2018). The advertising budget should be relevant to the potential sales impact of the campaign. This, in turn, will reflect the characteristics of the product being advertised. In today's world, advertising uses every possible medium to get its message through. It does this via television, print (newspapers, magazines, journals), radio, press, internet, direct selling, hoardings, mailers, contests, sponsorships, posters, clothes, events, colours, sounds, visuals and even people (The Economics Times, 2021).

Marketing is defined as a job that involves encouraging people to buy a product or service (Cambridge Dictionary, 2021). At its core, marketing seeks to take a product or service, identify its ideal customers, and draw the customers' attention to the product or service available (Twin, 2020). Consequently, a marketing plan for one product might be very different from that for another product (MacNamara, 2021). Understanding the marketplace constitutes the first step of the marketing process, which implies that the market or markets in which the company operates represent the third knowledge object of the marketing function (Aguirrezabalaga, Saenz \& Ritala, 2020). Generally, it is different from social marketing which seeks to develop and integrate marketing concepts with other approaches to influence behaviours that benefit individuals and communities for the greater social good (Zainuddin, 2020).

The marketing also stresses the importance of the brand experience. It stresses that brand experience concerns the interactions between the brand and the desired targeted consumer. Importantly, it requires deep and varied knowledge of the consumer of the brand (Cheutchouk, Veloutsou \& Paton, 2021). The 
relationship between the brand and consumers must be stable and long term, and it should be based on an in-depth understanding of the consumers (Kwon, Jung, Choi \& Kim, 2020).

Presently, there is an increasing influence of digitalisation and the application of ICT on business and performance. Naturally, modern marketing is more ICT driven. It entails content marketing (focuses on creating and distributing information relevant to prospects' needs), inbound marketing (earn the attention of customers), social media marketing (focuses on providing users with content they find valuable and want to share across their social networks), search engine optimisation (appears among the top unpaid search results on search engines) and search engine marketing (a tool that companies use to grow their website traffic through paid online advertising (Woschnick, 2021). While on one hand, some businesses such as Small and Medium Enterprises (SMEs) actively utilises the ICT because these technologies aid them in rivalling with bigger-sized businesses, however, on the other hand, some SMEs may lack financial resources, expertise, and suitable solutions in ICT utilisation (Kazakov, RuizAlba \& Munoz, 2021).

Marketing is constantly evolving. Modern marketing focuses on the importance of the brand experience. It stresses that brand experience concerns the interactions between the brand and the desired targeted consumer. Importantly, it requires deep and varied knowledge of the consumer of the brand (Cheutchouk, Veloutsou \& Paton, 2021). The relationship between the brand and consumers must be stable and long term, and it should be based on an in-depth understanding of the consumers (Kwon, Jung, Choi, Kim, 2020). Furthermore, modern marketing now develops a stakeholder marketing concept which acknowledges the process of value creation in the organisation by developing network relationships with different interest groups connected with the business. The organisation must develop relationships, inspire their stakeholders and create communities where everyone tries to give their best to deliver the value the businesses promise (Chahal, Kumar, Kumari \& Sethi, 2020). Critically, this is the difference from the conventional marketing strategies which focused more on customers and profit maximisation of the business

\section{The Publicity, Advertising and Marketing of Legal Practice}

Abbott (1982) highlighted the function of a lawyer in the legal profession. A lawyer's duty is to discover the law and to embody law in the social structure of the nation by the demonstration of laws before the courts. He mentioned that men look upon a lawyer as a fighter. Nevertheless, he is opined that the true lawyer is pre-eminently a peace-maker who has a perception of justice and righteousness, and incorporates justice and righteousness into the laws of the commonwealth, and later applies justice and righteousness to the daily affairs of men (Abbott, 1982). With regards to the duties of a lawyer, case law seems to recognise that every counsel has a duty to his client to fearlessly raise every issue, advance every argument, and ask every question, however distasteful, which he thinks will help his client's case. But, as an officer of the court who is concerned in the administration of justice, he has an overriding duty to the court, to the standards of his profession and the public (Rondel $\mathrm{v}$ Worsley [1969]).

Publicity, advertising and marketing in legal profession is restricted mainly because of three principles. Firstly, it is a well-established principle that firstly, a lawyer stands in a fiduciary relationship to his client. It is the absolute highest duty imposed by law on a lawyer (Sears, 2020). It requires the lawyer to put his client's interest above the concerns of others (Wilson, 2020). The core concept of fiduciary duties and the relationship of fiduciary has been observed by Rotman. He suggested that the core concept of fiduciary law is its purpose of (a) maintaining the integrity of socially and economically important or necessary relationships of high trust and confidence that (b) create beneficiaries' implicit dependency and particular vulnerability to (c) fiduciaries' duties of honesty, integrity, fairness, and utmost good faith that (d) establish the parameters of fiduciaries' acceptable conduct toward their beneficiaries (e) within the fiduciary elements of their interaction. He contended that fiduciary duties govern the relationship between fiduciaries and beneficiaries and establish the parameters of the former's acceptable conduct toward the latter within the fiduciary elements of their interaction (Rotman, 2017). Concerning the fiduciary relationship of solicitor-client privilege, Dodek recommended that the 
three pillars of dignity, privacy and autonomy must always be kept in focus. He stressed that Courts are to hold solicitor-client privilege in the highest regard and protect it zealously without challenging any of their assumptions about it (Dodek, 2010).

Secondly, a legal profession is a profession and not a business (Wilkins, Trubek \&Fong, 2020). It is a classic example of professionalisation, through which its members, use their expertise to accomplish complicated tasks and abstract work (Riordan \& Osterman, 2016). Therefore, it differs from a business or trade. Businesses endeavours are fuelled by the quest for financial gain, while the legal profession is fuelled by a duty to serve the public (Bagust, 2013). Therefore, a strict distinction must be drawn between the two by not allowing business-oriented practices (Abdullah, Kamarulzaman \&Farinda, 2008).

Thirdly, publicity and marketing are also objected to on the ground that it is professionally undignified. Lawyers predominantly succeed in marketing their legal services in a unique way where they relied on the networks of personal relationships and word-of-mouth which brought them clients to maintain a profitable business (Wan Hussain et al., 2010). Whereas, most of the business activities will succeed because of promotion activities, especially advertising (Wong, 2019). Nonetheless, Vogel observed that the legal profession together with other traditional professions such as medicine, nursing and engineering, has such privilege of self-government. This means that its members themselves, and not some government agencies, regulate, discipline and control all aspects of the practice of their profession (Vogel, 1986).

\section{Methodology}

This paper adopts a qualitative research methodology as it envisages the most appropriate way to obtain suitable data. Two approaches are utilised in this paper, namely, the doctrinal and comparative approaches. The doctrinal approach is a method that focuses on content analysis of statutes, case laws and other legal resources as they are. This method is used because this paper seeks to do an in-depth analysis of the law governing the publicity, advertising and marketing of the legal profession in Malaysia. Thus, firstly, this paper analyses the LPA 1976, LPPER 1978, LPPR 2001 and the relevant cases as the primary sources of law. Secondly, analysing the secondary sources of law including, textbooks, journal articles, newspaper articles and online sources. Thirdly, conducting a comparative study by analysing the primary and secondary sources of law in the EU, UK, Singapore, Australia and US.

\section{The Legal Profession in Malaysia}

The legal profession in Malaysia is regulated by the LPA 1976. Bar Council is the governing body of legal practice in Malaysia that is empowered to manage the affairs of the Malaysian Bar as envisaged in section 47 of LPA 1976. Section 77 of the LPA 1976 empowers the Bar Council with the approval of the Attorney General to make rules for regulating the professional practice, etiquette, conduct and discipline of advocates and solicitors. Thus, the establishment of the LPPER 1978 and LPPR 2001 to regulate the etiquette, conduct and manners of advocates and solicitors in Malaysia. The LPPR 2001 in particular intended to regulate how advocates and solicitors would publicise and advertise their practice.

Legal practitioners in Malaysia is known as Advocate and Solicitor. Currently, there are 20,384 Advocates and Solicitors in Malaysia (Malaysian Bar, 2021). Advocate and solicitor as defined under section 3 of the Legal LPA 1976 is an advocate and solicitor of the High Court admitted and enrolled under the LPA 1976 or under any other written law prior to the coming of the said LPA 1976. In the public eye, an advocate and solicitor are more commonly known as a lawyer. Importantly, one of the roles of a lawyer is to promote the public interest, serving the cause of justice. In addition to this, a lawyer must be faithful to the client's trust but not limited to uphold his professional, justice without fear. 
In doing so a lawyer is bound to the provisions of LPA 1976, certain rules and regulations imposed by the Malaysian Bar, a body corporate and thus the Disciplinary Board is established under section 93 of the LPA 1976 to investigate any misconducts of the lawyer upon receipt a complaint lodged by a public/client. The Malaysian Bar was established about 92 years ago covering the legal practitioners in the Federated Malay States vide Advocates \& Solicitors Ordinance 1914 before the LPA 1976 was introduced. The Malaysian Bar and Bar Council play a significant role to the members as well as accommodating the public confidence in lawyers. To achieve these objectives the Bar Council was established to represent the Malaysian Bar with a role among other things to make rules regarding practice and etiquette of the profession, examine and report on current legislation and oversee standards and discipline among members of the Bar. Section 42 of LPA 1976 provides the list and details of objectives, powers and purpose of the Malaysian Bar being formed up.

Whereas the establishment of the Disciplinary Board which consists of a quorum headed by an appointed chairman is responsible to conduct disciplinary proceedings against a lawyer for misconduct or omission to act in accordance with the rules and regulations set up in the LPA 1976. Section 94 of the LPA 1976 empowers the Disciplinary Board to strike off the Roll, suspend for misconduct of the lawyers. Section 94 (1) (2) and (3) (a) to (o) of the LPA1976 has listed out the illustrations that are tantamount to "misconduct" of the lawyers or omission in performing his duty. The Malaysian Bar has to act strictly in order to uphold its role and dignity and the good name of the profession from being tarnished. In a recent press statement issued by the Malaysian Bar pertaining to the misconduct of the lawyers the President of the Malaysian Bar, Kalidas (2021), has said "We take matters pertaining to the integrity of our Members with utmost seriousness. We do not condone such actions; and if it indeed proven to be true, it is considered a misconduct". Hence a lawyer is duty-bound and subject to the above bodies in performing and discharging his duties toward his profession as an advocate and solicitor.

\section{The Publicity, Advertising and Marketing of Legal Practice}

The LPPR 2001 in particular intended to regulate how advocates and solicitors would publicise, advertise and market their practice. In contrast to the business or trade, every advocate and solicitor, whether he is practising as a sole proprietor or as a partner, an employee or a consultant of a firm (rule 3 of the LPPR 2001), he shall not to publicise except in accordance with the rule 4 of the LPPR 2001. Section 77(3) of the Legal Profession Act 1976 provides that any advocate and solicitor who fails to comply with rule 3 and 4 of the LPPR 2001 may be liable for disciplinary proceedings as the Bar Council, with the approval of the Attorney General may make rules regulating the professional practice, etiquette, conduct and discipline of advocates and solicitors (section 77 (1) of the LPA 1976).

The advocate and solicitor are only allowed to publicise the "Approved Information" as provided in rule 2 of LPPR 2001 in any publication and marketing of himself and his practices. Basically, the LPPR 2001 does not ban all means of publicity, advertisement or marketing. Lawyers and law firms are allowed to hold themselves out as lawyers and provides the necessary information to the public to differentiate themselves from and to compete with others. The LPPR 2001 provides 18 types of Approved Information. For example, lawyers may share with the public their name, contact detail, background, historical data, designation, position, qualification, area of practice and other information approved in writing by the Bar Council. Details on advertisements in the legal and non-legal directories are provided by rule 8 of LPPR 2001. Furthermore, rule 13 of the LPPR restricts the persons to whom publications may be sent. It only allows an advocate and solicitor to publish journals, magazines and newsletters. However, such materials may only be distributed to limited persons. Firstly, the employees or any other advocate and solicitor practicing in his firm. Secondly, any of the firm's existing and potential clients. Thirdly, any person with professional dealings with the firm. The published materials may only be displayed at the firm. Rule 21 of LPPR 2001 further states restrictions on publicity through electronic media. In particular, the Rule provides that any publicity placed in, stored in or transmitted through the electronic media must be done in such manner as determined by the Bar Council. The publicity shall not contain any information pertaining to the advocate and solicitor or his firm, except Approved Information. Rule 31 of the LPPER 1978 requires every advocate and solicitor 
to uphold the dignity and high standing of his profession at all times. Rule 48 of the LPPR 2001 prohibits the advocate and solicitor from publishing his photograph as a member of the Bar in the press or any periodical. Rule 52 of the LPPER 1978 prohibit the act of procuring business through a tout.

In essence, legal practitioners are not allowed to publicise to the public at large. Any act which is not in line with the rules will amount to misconduct that warrants disciplinary proceeding as envisaged in section 94(1)(2)(3)(k) of the LPA 1976. This is evident from the case of Majlis Peguam v Dato Sri Dr Muhammad Shafee Abdullah [2016]. In this case, the disciplinary committee which conducted the inquiry into the complaints concluded that the respondent had in his interview with the journalist publicised himself and his firm of solicitors and was thus in breach of the LPPR 2001. As such, the Disciplinary Board imposed a fine of RM5,000 on the respondent. The Federal Court agreed with the Court of Appeal that the words describing the respondent as 'a high profile' lawyer' and 'a top lawyer' in the first article were the journalist's remarks. These remarks reflected the journalist's personal opinion and this was something which the respondent could not have prevented the journalist from expressing. Further, there did not appear to be any evidence to show that the respondent had solicited the interview or that the respondent had wanted to publicise his practice or his firm.

To summarise the LPPER 2001in a loose layman term and understanding, lawyers are allowed to tell the public in many ways, almost everything about themselves in their professional identity so long it does not gain business by bragging, misleading or damaging the dignity of lawyers.

\section{Relevant Laws and Regulations}

However, lawyers need to consider some legal issues concerning publicity, marketing and advertising such as intellectual property and data privacy (Neilpatel, 2021). The advertisement may also contain misleading, wrong information or manipulating statements (Asuhaime et at al., 2017). Accordingly, the advertising industry in Malaysia is largely self-regulated following various laws, regulations, codes and guidelines (Wong \& Teoh, 2021). Therefore, lawyers may also need to comply with the laws such as the Communications and Multimedia Act 1998, Trade Description Act 1972, Contracts Act 1950, Electronic Commerce Act 2006, Penal Code, Indecent Advertisement Act 1953 and Personal Data Protection Act 2010.

In this modern high technology, lawyers tend to advertise and marketing their legal services by using digital tools such as through social media and law firm websites. Advertising online to connect with clients is increasingly common for lawyers. Apart from the above laws and regulations lawyers may also think and carefully consider other relevant laws such as Cyberlaw or IT law (the Law of the Internet) which protect the internet and other online communication technologies which lead to a cyber-crime act.

Few other laws and regulations that may assist the usage of advertisement and regulations are such as Computer Crimes Act 1997, Digital Signature Act 1997, Sedition Act 1948, case laws and other specific guideline and policies. Some legal frameworks need to be set up under these various Acts to prevent the misuse of data that may lead to cybercrime acts. Hence lawyers are duty-bound to adhere to the requirements provided mainly in the LPPR 2001, LPA 1976 and any other laws and regulations mentioned above.

\section{The Need to Re-Examine the LPPR 2001}

The opinion on the adequacy of LPPR 2001 in legalising the publicity and legal marketing of lawyers are differing. Chew (2019) opined that if each law office was free to scramble for the more desirable clients and cases, the profession itself would lack necessary unity. Lawyers are generally not in competition for business with non-lawyers. Hence, the limited publicity rights are merely removing competition by advertisement between lawyers and law firms only. Contrary to this view, Mohamed On and Shapiee (2009) stated that lawyers are also exposed to competition from other professions which could jeopardise the chances of lawyers securing certain types of jobs or services if the publicity 
rules remain unchanged. For instance, accountants, bankers and business consultants who are not restricted from publicising their services may deprive lawyers of jobs involving tax advice, security documents drafting and business-related legal advice.

Kuala Lumpur Bar Committee, likewise, has different views from Chew. It argued that taken as a whole, the prescriptive manner in which the LPPR 2001 is drafted leaves little room for the legal profession to distinguish themselves, thereby lowering the competitive tension and provides limited opportunity for them to share legal developments with the public at large (Kuala Lumpur Bar Committee Consultation Paper, 2019). Wei (2020) added that this is a serious drawback as legal publicity, is an important means to cultivate and improve citizens' legal awareness and legal literacy. It is also a fundamental project for comprehensively advancing the rule of law. This argument is not new. Wan Hussain et al in 2010 has strongly argued that The LPPR 2001 has become a barrier to legal firms as it restricted certain marketing activities in legal service particularly in the use of electronic media such as television and radio. This limitation is a real barrier to access to justice because laypersons simply do not know how to go about finding lawyers or assessing or judging the skill set of a particular counsel. The freedom of the client to select his lawyer may also be severely regimented. On top of this, Mohamed On (2019) also highlighted that strict publicity rules have also reduced competition amongst lawyers and eventually resulted in high legal fees being charged to clients. The present compromise of restricted publicity is, perhaps, subject to improvement; but at least it is a custom familiar to many persons and should serve until some better answer is discovered.

Furthermore, as the number of lawyers will be increasing from year to year, the competition among the legal firms to get the business and clients will be increased as well (Wong, 2019). This may cause a grave problem to the lawyers as legal marketing requires a unique and different skill. As rightly pointed by AsOne (2021) it is a skill distinct from the legal qualifications of an advocate and solicitor. The lawyers must fully embrace and utilise the advancement of the ICT. The legal marketing potential using the ICT has been unveiled by big organisations and it became popular as a medium of powerful marketing to target customers efficiently (Wan Hussain et al, 2010). This has become more important now. Undoubtedly, COVID-19 has been a huge disruptor of the legal sector and how law firms reach their existing and potential new clients. Law firms that have embraced these changes quickly and wholeheartedly are in a strong position as the pandemic situation continue to evolve into the future (The Drum, 2021), regardless of whether the firms are established or new (Kasper \& Kozma, 2019).

Most legal firms are attempting to market their services in a new, different and creative way. Abdullah, Kamarulzaman and Farinda in 2008 suggested that in maintaining and expanding their client base, legal firms should not ignore the marketing tools and strategies to generate high quality of service and profit. In terms of marketing strategies, certain marketing tools can be exploited by legal firms such as television advertising, viral marketing, brand awareness and online marketing. However, the legal firms are bound to adhere strictly to the LPPR 2001. There were calls for the reform of the LPPR 2001 before. However, the LPPR 2001 still remain intact.

Wong in 2019 and Wan Hussain et al in 2010 suggested that the LPPR 2001 be reviewed and revised to keep abreast with the current need of the legal practitioners as well as the public. Legal marketing will provide the public with useful information and at the same time give significance to the profession image. For example, Internet marketing can help lawyers to know and find clients more easily which in turn generates more profits for them. Likewise, it will also be less tricky for the members of the public to locate competent lawyers and should the lawyers be allowed to provide information as to their fee structures, this could eliminate the fear of service price which at times becomes a hindrance to counsel engagement, especially by those with modest incomes, as the public is no longer being kept in the dark of the necessary information (Kasper \& Kozma, 2019). Wong (2019) noted the importance of internet legal marketing via mass media and social media. Gone were the days where the public will have to go door to door to find the law firms. Having little to no knowledge of legal services, many often seek recourse to internet searches to find suitable legal practitioners. This is more pertinent now as of the current situation, especially during COVID-19 and towards the new normal, for many people use social media while at home (Lestari \& Famiola, 2021). Abdullah and Panneerselvam (2019) agreed that lawyers are utilising social media as a means of gaining networking and publicity prospects in 
furthering their business. Social media sites such as LinkedIn, Facebook and Twitter are often used to share their legal knowledge and experiences to the general public as well as inviting further legal discussion with other lawyers, contributing to their public exposure.

Sharing their legal experiences and knowledge on mass media and social media allows the public to ascertain the lawyers' area of expertise. Mohamad On (2014) opined that the restrictions placed by the LPPR 2001 stripped a fundamental right of the public to evaluate the suitability of a legal practitioner to handle their respective case and to make an informed choice for legal representation.

Arguably, although allowing lawyers to utilise social media will allow for effective marketing and developing professional networking with fellow legal brethren, one must consider the ethical conundrums that may arise in the improper use of social media, which may result in breaches of various ethical rules such as confidentiality, competency and communication with clients, to name a few (Scarola, 2019). Nevertheless, Scarola noted that this must be addressed via developing competency in social media skills and relevant guidelines and should not deter lawyers from competently maximising social media as a form of marketing and professional networking.

Even in 2017, Varughese, the then President of Malaysian Bar has suggested that it was time to reconsider if the LPPR 2001 are too restrictive as part of a blueprint to revamp the country's legal profession (The Star, 2017). Kesavan, a former Chairman of the Bar Council, echoed the same sentiments, urging the liberalisation of the archaic rules to suit the changing media landscape, especially with ubiquitous social media usage nowadays (Anbalagan, 2021). The Kuala Lumpur Bar Committee Firms \& Group Practice Reform Committee set out a consultation paper in 2019 to proposed changes to the LPPR 2001 (Kuala Lumpur Bar Committee Consultation Paper, 2019). The proposals seek to liberalise the publicity rules that govern the legal profession, whilst trying to balance the interest of the public to make a more informed choice when seeking legal representation against safeguarding the public's trust and confidence in the legal profession by ensuring only credible information is disseminated. However, until today there are no changes made to the LPPR 2001.

Despite the recommendations given in legalising the publicity, advertising and marketing of lawyers in Malaysia, the LPPR 2001 clearly provides rules that an advocate and solicitor who publicises his practice of his firm within Malaysia shall not do so in a manner as will be likely to diminish public confidence in the legal profession or bring the legal profession into disrepute (rule 5(1)(a)(i) LPPR 2001). Moreover, the rule is clear that an advocate and solicitor in Malaysia is prohibited from publishing his photograph as a member of the Bar in the press or any periodical (rule 48 of the Legal Profession (Practice and Etiquette) Rules 1978. It has to be highlighted that failure to follow these rules shall cause losses to an advocate and solicitor because if he has been guilty of any misconduct, he shall be liable to penalties or punishments under section 94(2) (a), (b), (c) and (d) of the Legal profession Act 1976.

\section{The Position in Other Jurisdictions}

While our LPPR 2001 remains the same, the relevant professional and governing bodies of the legal profession such as in the EU, UK, Singapore and Australia, have over the years refined their publicity rules to espouse a more liberal regime. Lawyers are permitted to widely advertise their specialisation and expertise in journals and electronic media.

Even the EU has taken positive initiatives in this area. Historically, the legal professions in European countries frowned upon or prohibited advertising by lawyers. However, the adoption of the Code of Conduct for Lawyers in the European Union (CCBE Code), which permits lawyer advertising, along with the Lawyers' Services Directive, the Diploma Directive, and decisions of the European Court of Justice, led many Member States of the EU to review the rules of practice and the codes of conduct for their legal professions. As a result, many EU Member States abandoned their traditional rules prohibiting lawyer advertising in favour of permitting some form of advertising by lawyers (Hill, 2003). 
In England and Wales, in November 2001, the Solicitors' Publicity Code of 2001 replaced the Solicitors' Publicity Code of 1990. Deleting "bad taste" as a prohibition of publicity along with detailed rules about the manner of advertising, the Solicitors' Publicity Code 2001 simply states that "publicity must not be misleading or inaccurate." The new Code prohibits unsolicited visits or telephone calls to members of the public, however, "member of the public" is narrowly construed, targeting lay individuals in its prohibition, rather than professional or business entities. Solicitors in England and Wales who advertise in jurisdictions outside of England and Wales must comply with the Solicitors' Publicity Code, as well as the rules relating to publicity in the jurisdiction where they advertise (Wong,2019). Concerning the type of information that can be advertised, the Solicitors' Code of Conduct 2007 does not entail any specific detail. Solicitors may advertise any information pertaining to their practice, including areas of expertise, as long as the information is accurate and not misleading (Mohamed On, 2014).

In Scotland, advertising by solicitors is governed by the Solicitors (Scotland) (Advertising and Promotion) Practice Rules 1995. In Northern Ireland, Solicitors in Northern Ireland are currently permitted to advertise, barristers are not. The Solicitors Practice Regulations of 1997, which are consolidate and simplifies "early regulations with the principal aim of regulating the message, not the medium,” (Wong, 2019).

The Legal Profession (Publicity) Rules ("Publicity Rules") in Singapore were brought into force in 1993. They have been liberalised over the years to allow solicitors to publicise their law practices in any manner as well as to participate in any third party or client publicity, so long as they comply with the general ethical principles set out in the Publicity Rules. These ethical principles include the prohibition against touting and the need to maintain the dignity of the legal profession. They underscore the values of "honour, integrity and honesty" that are integral to the legal profession and recognise that the legal profession should not "become a mere calling which its members practise as a means of livelihood and not in the spirit of a public service" (The Law Society of Singapore, 2021). Then a legal practitioner can now present a news show on the radio or television, has advertisements through the press or television, filming at law practice's office premises, a television commercial advertising his law practice and complimentary advertising in a newspaper (The Council of the Law Society of Singapore, 2018). In a study conducted by Chow and Tsui-Auch (2019), the partners of a law firm in Singapore agreed that law firms must take initiative in developing public relation and marketing skills of their lawyers to stay competitive in the market. A balance must be struck between meeting the commercial needs of the firm via marketing and retaining the firm's distinction through the quality of its work.

In Australia, law firms are starting to see the value in legal content marketing. Digital marketing for lawyers involves using the information on the firms' website, blogs, case summaries, landing pages or lawyer's profiles. This is to inform and attract more clients to their page (Legal Writers, 2021). Advertising and marketing are regulated by Schedule 2 of the Competition and Consumer Act 2011 (Cth) (the Australian Consumer Law or ACL), which contains the general overriding obligation on advertisers to ensure that advertisements are not false, misleading, or deceptive. All products and services advertised in Australia must comply with the Australian Consumer Law. This law is enforced by the Australian Competition and Consumer Commission (ACCC), an Australian government body, but competitors and consumers are also able to take legal action against advertisers for breach of the law under the ACL (Wong, 2019). On top of this, in New South Wales, by section 85 of the Legal Profession Act 2004, lawyers may advertise in any way they deem fit and this may include advertising their expertise provided this has been accredited by the Bar Council or the Law Society Council (Mohamed On, 2014).

Outside these common law jurisdictions, the United States ("US") has long liberalised its publicity rules since Bates v State Bar of Arizona in 1977. The US Supreme Court, in this historic decision, had allowed truthful advertising of lawyers' services which is in line with the right to freedom of speech in the First and Fourteenth Amendments. The change in the rule is also parallel to the American Bar Association Code of Professional Responsibility which obliges lawyers to ensure wide accessibility of their services to laypersons (Kasper \& Kozma, 2019). Furthermore, the American Bar Association 
Model Rules of Professional Conduct does not limit the type of information that can be advertised by lawyers, as long as the information is not false, misleading or deceiving. Such information encompasses the firms' names, addresses, contact numbers, types of service rendered, fee structures, modes of payment, lawyers' foreign language proficiency, clients' names (with clients' written consent), etc (Mohamed On, 2019).

\section{Conclusion}

No doubt that the legal profession is noble and one of the most important professions to society with its long well recognised reputation. It discharges its expected duties without fear or favour to the court, clients, society and plays important role in the development of the nation. Today the legal profession is in the middle of rapid and continuous change. The world is vibrating with the wonders of ICT, shifting into industrial revolutions 4.0 and getting closer as the result of globalisation. It also resulted in the emerging digital and new economies. This creates new opportunities and demands. The potential clients are now spread out around the world. Accordingly, the legal profession needs to determine the best methods to adapt and evaluating the changes. For one, it may need to recognise that the legal profession, to a certain extent, constitutes a business activity and the need to adapt to the changes out of the current norms and demand.

In conclusion, there is an urgent need to identify the areas for reform of the LPPR 2001 to legalise the publicity, advertising and marketing of the legal profession in Malaysia. This reform is to ensure that the members of the profession retain their competitive drive and innovate, have a global presence and provide a global skillset. Simultaneously, these changes will enable public to make a more informed choice when seeking legal representation.

\section{Acknowledgement}

The authors would like to express their gratitude for the financial support from the Faculty of Law, Universiti Teknologi MARA under the Lex Praesta Research Grant 2021 granted for this research.

\section{References}

Abdullah, A., Kamarulzaman,Y., \& Farinda, A. B. (2008). Legal Services and Marketing Limitations: A Focus on SME in Malaysia. International Review of Business Research Papers, 4(5).

Abdullah, Z., \& Panneerselvam, T. L. (2019). The Relationships Between Social Networking and Individual Job Performance of Law Sector in Malaysia. Journal of Education and Social Sciences, 12(2), 92-101. https://www.jesoc.com/issue/volume-12-february-2019-issue-2/.

Aguirrezabalaga, C. P., Saenz, J., \& Ritala, P. (2020). Marketing-Specific Intellectual Capital: Conceptualization, Scale Development and Empirical Illustration. Journal of Intellectual Capital 21(6). https://www.emerald.com/insight/1469-1930.htm.

Anbalagan, V. (2021). Time to Review Archaic Publicity Rules, Lawyers Tell Bar Council. Free Malaysia Today (FMT), https://www.freemalaysiatoday.com/category/nation/2021/06/15/time to-review-archaic-publicity-rules-lawyers-tell-bar-council/.

AsOne (2021). What's the Point? The Importance of Legal Marketing Services, accessed on 10 June 2021 at https://asone.co.uk/legal-marketing-services/.

Asuhaime, F. A., Pauzai, N. A., Yusob, M. L., \& Asari, K. (2017). Rules on Advertisement in Malaysia. World Applied Sciences Journal, 35(9), 1723-1729, 2017.

Bagust, J. (2013). The Legal Profession and the Business of Law. Sydeny Law Review, 35(26).

Cambridge Dictionary. (2021). Publicity, acdessed on 19 September 2021 at https://dictionary.cambridge.org/dictionary/english/publicity.

Celvarajah, R. R. (2006). History of the Malaysian Bar, The Early beginning of the Bar Council and the Struggles of the Bar, accessed on 19 September 2021 at https://www.malaysianbar.org.my>echoes _of_the_past. 
Chahal, H, Kumar, P., Kumari, \& N. Sethi. (2021). Exploration of Stakeholder Marketing Orientation and its Impact on Business Performance in Indian Pharmaceutical Marketing Companies, International. Journal of Pharmaceutical and Healthcare Marketing, 15(1). https://www.emerald.com/insight/1750-6123.htm.

Chevtchouk, Y., Veloutsou, C., \&Paton, R. A. (2021). The Experience - Economy Revisited: An Interdisciplinary Perspective and Research Agenda. Journal of Product \& Brand Management, accessed on 19 September 2021 at https://www.emerald.com/insight/1061-0421.htm.

Chew, Y. (2019). Defending the Legal Profession Publicity Rules, assessed on 10 June 2021 at https://yitinglawoffice.wixsite.com/yitinglawoffice/post/defending-the-legal-professionpublicity-rule.

Chia, Lee \& Associates. (2018). Basics of Security Law in Malaysia assessed on 19 September 2021 at https://chialee.com.my>basic of cyber security law.

Chow, D. Y., \& Tsui-Auch, L. S. (2020). Coping with Commodification: Hybrid strategies in Asian law firms. Asia Pacific Journal of Management, 37(3), 763-793. https://ideas.repec.org/a/kap/asiapa/v37y2020i3d10.1007_s10490-018-9629-1.html.

Devika, N. (2021). Definitions of Advertising, Economics Discussion, accessed on 19 September 2021 at https://www.economicsdiscussion.net/advertising/definitions-of-advertising/31793.

Hill, L. L. (2003). Publicity Rules of the Legal Professions Within the United Kingdom. Arizona Journal of International and Comparative Law, 20(2). https://chialee.com.my>basic of cyber security law.

Kalida, A. G. (2021). Press Release: The Malaysian Bar Does Not Tolerate Unscrupulous Behaviour By Lawyer, assessed on 19 September 2021 at https://www.malaysianbar.org.my.

Kasper, E. T., \& Kozma, T. A. (2019). Did Five Supreme Court Justices Go Completely Bonkers: Saul Goodman, Legal Advertising, and The First Amendment Since Bates v. State Bar of Arizona. Cardozo Arts \& Entertainment Law Journal, 37(2), 337-372.

Kazakov, S., Ruiz-Alba, J. L., \& Munoz, M. M. (2021). The Impact of Information and Communication Technology and Internal Market Orientation Blending on Organisational Performance in Small and Medium Enterprises. European Journal of Management and Business Economics, 30(2). https://www.emerald.com/insight/2444-8494.htm.

Kotler, P. (1984). Marketing Essentials, Northwestern University. Prentice-Hall, Inc.

Kuala Lumpur Bar Committee. (2019). Rethinking the Legal Profession (Publicity) Rules 2001: A Consultation Paper, assessed on 13 June 2021 at https://www.klbar.org.my/wpcontent/uploads/2019/08/2019.08.22-Draft_Consultation_Paper_Publicity_Rules.pdf.

Kwan, J. H., Jung, S. H., Choi, H. J., \& Kim, K. (2020). Antecedent Factors that Affect Restaurant Brand Trust and Brand Loyalty: Focusing on US and Korean Consumers, Journal of Product \& Brand Management, accessed on 19 September 2021 at ttps://www.emerald.com/insight/10610421.htm.

Lake, L. (2021), What is Publicity?,the BalanceSmall Business, accessed on 19 September 2021 at https://www.thebalancesmb.com/what-is-publicity-2295550.

Legal Writers. (2021). Digital Marketing for Lawyers, accessed on 10 June 2021 at https://www.legalwriters.com.au/digital-marketing-for-lawyers/.

Lestari, W. L., Famiola, M. (2021). Innovation of Business Model to Expand New Revenue Stream and Exploring Willingness to Pay in Café, Restaurant and Business Sector to Waste Logistic Service in Urban Area: Study Case of NYAMPIH. Malaysian Journal of Social Sciences and Humanities (MJSSH), 6(7), 350-359.

MacNamara, C. (2021). Basic Definitions: Advertising, Marketing, Promotion, Public Relations and Publicity, and Sales, Free Management Library, accessed on 19 September 2021 at ttps://managementhelp.org/marketing/advertising/defined.htm.

Majlis Peguam v Dato Sri Dr Muhammad Shafee Abdullah [2016] 5 MLJ 572.

MBA Skool Team. (2021). Publicity Meaning, Meaning, Types and Examples, MBA Skool, accessed on 19 September 2021 at https://www.mbaskool.com/business-concepts/marketing-andstrategy-terms/13418-publicity.html.

Mohamed On, H. (2014). Pengiklanan Bidang Kepakaran Peguam: Keperluannya dalam Membantu Bakal Klien Memilih Peguam. UUM Journal of Legal Studies, 5(1), 13-29.

Mohamed On, H. (2019). Pengiklanan Yuran Guaman oleh Peguam: Persepsi Awam dan Peguam. Asian Journal of Accounting and Governance, 12(0), 143-154. 
Mohamed On, H., \& Shapiee, R. (2009). Peraturan Publisiti Dalam Profesion Guaman: Justifikasi Ke Arah Penilaian Semula. Jurnal Undang-Undang Dan Masyarakat, 13(0), 96-114.

Neilpatel. (2021). Three Key Legal Issues Online Marketers Need to Know About, accessed on 17 July 2021 at https://neilpatel.com/blog/legal-issues-facing-online-marketers/.

Puspitasari, L., \& Mohamad Permana., R. S. (2018). Marketing Communication Strategy of National Indie Movies: A Case Study of Yogyakarta Indie Movies. Malaysian Journal of Social Sciences and Humanities (MJSSH), 3(2), 24-31.

Riordan, C., \& Osterman., P. (2016). Externalization of work By Corporate Law Firms: Implications For Careers and the Profession. The Structuring of Work in Organizations Research in the Sociology Organizations, 47, 333-361.

Rondel v Worsley [1969] 1 A.C. 191.

Rotman, L. I. (2017). Understanding Fiduciary Duties and Relationship Fiduciarity. McGill Law Journal, 62(4), 975-1042.

Scarola, C. T. (2019). What happens on Social Media Could Derail Your Legal Career: Teaching EProfessionalism in Experiential Learning. Vermont Law Review, 44(1), 165-208. https://heinonline.org/HOL/License.

Sears, R. (2020). The Duties and Obligations of Lawyers. South Texas Law Review, 61(1), 89.

Simon, S. (2020). Redefining the Concept of Advertising in Romanian: Between Need and Reality. Technium Social Sciences Journal, 13, 111-119.

The Council of the Law Society of Singapore. (2018). Practice Direction 6.2: Advertisement and Media Publicity, accessed on 10 June 2021 at https://www.lawsociety.org.sg/wpcontent/uploads/2020/03/66.-Advertisement-and-Media-Publicity-PD-6.2.1.pdf.

The Drum. (2021). How digitally effective is the UK's legal sector in 2021?, assessed on 10 June 2021 at https://www.thedrum.com/opinion/2021/04/08/how-digitally-effective-the-uk-s-legal-sector202.

The Economic Times. (2021). Definition of 'Advertising', The Economioc Times, accessed on 19 September 2021 at https://economictimes.indiatimes.com/definition/advertising.

The Law Society of Singapore. (2021). Ten Questions on the Publicity Rules, assessed on 13 June 2021 at https://v1.lawgazette.com.sg/2010-03/column1.htm.

The Star. (2017). Bar: It's Time to Rethink Publicity Rules for Lawyers, assessed on 10 June 2021 at https://www.thestar.com.my/news/nation/2017/05/29/bar-its-time-to-rethink-publicity-rules-forlawyers/.

Twin, A. (2020), Marketing, Investopedia, accessed on 19 September 2021 at https://www.investopedia.com/terms/m/marketing.asp.

Wan Hussain, W.M, Yaakub, N.I, Ab Rahman, Zainol,Z.A, Mujani, W.K. (2010). Internet Marketing Strategies for Lawyers in Malaysia: Read it, and Do it to Skyrocket Your Business. International Review of Business Research Papers, 6(6).

Wei, W. (2020). Study on the Characteristic Path of Legal Publicity in Ethnic Regions from the Perspective of Sociology of Law, 3rd International Conference on Economy Development and Social Sciences Research (EDSSR 2020).

Wilkins, D. B., Trubek, D. M., \& Fong, B. (2020). Globalization, Lawyers and Emerging Economies: The Rise, Transformation and Significance of the New Corporate Legal Ecosystem In India, Brazil and China. Harvard International Law Journal, 61(2).

Wilson, R. (2020). From Advocate to Party-Defenses for Lawyers Who Find Themselves in Litigation. Texas Law Review, 61(1), 43.

Wong Jin Nee \& Teoh. (2021). Advertising Compliance in Malaysia, accessed on 17 July 2021 at https://www.wjnt-law.com/intro/advertising-compliance-in-malaysia/.

Wong, H. S. (2019). Legal Profession and Marketing in Malaysia: Direction towards Hybrid Profession. International Journal of Recent Technology and Engineering (IJRTE), 8(2).

Woschnick, V. (2021). What Are the Top 10 Most Effective Marketing Strategies?, Widert Group, accessed on 19 September 2021 available at https://www.weidert.com/blog/top-10-mosteffective-marketing-strategies.

Yiting, C. (2019). Defending the Legal Profession Publicity Rules assessed on 19 September 2021 at https://yitinglawoffice.wixsite.com. 
Malaysian Journal of Social Sciences and Humanities (MJSSH), Volume 6, Issue 10, (page 443 - 455), 2021

DOI: https://doi.org/10.47405/mjssh.v6i10.1080

Zainuddin, N. (2020), Value Creation and Destruction in Social Marketing Services: A Review and Research Agenda, Journal of Services Marketing, accessed on 19 September 2021 at https://www.emerald.com/insight/0887-6045.htm. 